https://nv.nltu.edu.ua

https://doi.org/10.36930/40290803

Article received $21.09 .2019 \mathrm{p}$.

Article accepted 31.10.2019 p.

$@$ Correspondence author

O. Yu. Andreieva

УДК 630.4

andreeva-lena15@ukr.net

О. Ю. Андреєва ${ }^{1}$ А. В. Вишневський ${ }^{1}$, С. В. Болюх ${ }^{2}$

${ }^{l}$ Житомирський національний агроекологічний університет, м. Житомир, Украйна

2 Державне спеиіалізоване лісозахисне підприємство "Вінницялісозахист", м. Вінниия, Украйна

\title{
ДИНАМІКА ПОПУЛЯЦІЙ КОРОЇДІВ У СОСНОВИХ ЛІСАХ ЖИТОМИРСЬКОЇ ОБЛАСТІ
}

Установлено, що у всиханні соснових насаджень Житомирської області відіграють роль короїди, які заселяють дерева, ослаблені внаслідок посух і надмірного антропогенного навантаження. Висловлено гіпотезу, що після посухи 2009 р. відбулося два спалахи різних угруповань короїдів. Для підтвердження цієї гіпотези проаналізовано динаміку за 2013-2019 рр. популяційних показників найпоширеніших видів під час їхнього масового розмноження у лісах Житомирської області: великого (Tomicus piniperda) та малого (T. minor) соснових лубоїдів, а також верхівкового (Ips acuminatus) й шестизубчастого (I sexdentatus) короїдів. Під час аналізу даних стосовно поширеності, щільності поселення, продукції й енергії розмноження цих видів, одержаних на 550 палетках із 61 модельного дерева, з'ясовано, що в комплексі короїдів в осередках всихання до 2014 р. переважали соснові лубоїди, а з 2015 р. - верхівковий і шестизубчастий короїди, які мають декілька поколінь на рік. Показано, що основні тенденції розвитку комплексу короїдів у соснових насадженнях Житомирської області в роки досліджень визначала динаміка популяцій домінантного виду - верхівкового короїда. Значення показників поширеності, щільності поселень, продукції та енергії розмноження короїдів свідчать про посилення з 2016 р. внутрішньовидової конкуренції в популяції верхівкового короїда, а у 2018-2019 pр. - також міжвидової конкуренції. 3 огляду на дію конкуренції та накопиченням ентомофагів в осередках всихання варто очікувати згасання спалахів масового розмноження короїдів.

Ключові слова: площа осередків; популяційні показники; поширеність; щільність поселень; продукція потомства; енергія розмноження.

Вступ. Короїди (Coleoptera: Curculionidae: Scolytinae) $є$ складовими лісових екосистем і заселяють ослаблені різною мірою дерева (Biedermann et al., 2019; Jaime et al., 2019; Tkach \& Meshkova, 2019). У випадку посухи, вітровалу, пожежі або надмірного антропогенного навантаження збільшується кількість ослаблених дерев у лісі, що створює умови для розмноження короїдів (Meshkova \& Borysenko, 2017, 2018; Andreieva et al., 2018 a, 2018 b). У міру розвитку спалаху короїдів потомству не вистачає доступних для заселення дерев, i осередок згасає унаслідок міграції частини популяції та відпаду особин на різних стадіях внаслідок конкуренції й діяльності ентомофагів (MacQuarrie et al., 2016; Orlov et al., 2018), а іноді й під впливом певних погодних умов. Останнім часом, унаслідок зміни клімату та росту антропогенного навантаження, у лісах збільшилася кількість дерев, які придатні для заселення короїдами.

Водночас, зміна клімату сприяла прискоренню розвитку комах, зокрема короїдів (Neuvonen \& Viiri, 2017; Shvidenko et al., 2017; Okland et al, 2019), і переваги в заселенні дерев отримали види, спроможні розвиватися у декількох поколіннях на рік (Meshkova et al., 2017). Ці види можуть заселяти дерева впродовж майже всього вегетаційного періоду, а також ослабляти їх під час до- даткового живлення та внаслідок перенесення фітопатогенних організмів (Davydenko et al., 2017; Meshkova, 2017, 2019). Санітарний стан соснових лісів (Рinus sylvestris L.) Житомирської обл. різко погіршився після посухи 2009 p. (Andreieva, 2016; Andreieva \& Goychuk, 2018), але його пояснювали спочатку негативним впливом кліматичних чинників. Під час обстеження насаджень, що всихали, виявляли переважно поселення чотирьох видів короїдів: великого (Tomicus piniperda (Linnaeus, 1758)) та малого (T. minor (Hartig, 1834)) соснових лубоїдів, а також верхівкового (Ips acuminatus (Gyllenhal, 1827)) й шестизубчастого (I sexdentatus (Boerner, 1767)) короїдів. У такі самі роки зареєстровано всихання соснових лісів із участю короїдів у Волинській області (Borodavka, et al., 2016; Getmanchuk et al., 2017), Білоруci (Sazonov et al., 2017; Kukhta \& Sazonov, 2019) та Польщi (Skrzecz \& Perlińska, 2018; Sierota et al., 2019).

Площа осередків усихання соснових насаджень за декілька років не зменшилася, а навпаки, з 2015 р. почала стрімко збільшуватися, і було визнано, що безпосередньо відпад дерев спричиняють короїди, хоча ослаблення насаджень відбулося під впливом як погодних умов, так і антропогенного навантаження. При цьому співвідношення окремих видів шкідників змінилося на

Інформація про авторів:

Андреєва Олена Юріївна, канд. с.-г. наук, доцент, кафедра експлуатації лісових ресурсів. Email: andreeva-lena15@ukr.net; https://orcid.org/0000-0003-0851-800X

Вишневський Анатолій Васильович, канд. с.-г. наук, доцент, кафедра експлуатації лісових ресурсів. Email: vishnev.tolik@ukr.net; https://orcid.org/0000-0001-5381-1219

Болюх Олександр Григорович, головний лісопатолог. Email: agboluh@ukr.net

Цитування за ДСтУ: Андреєва О. Ю., Вишневський А. В., Болюх С. В. Динаміка популяцій короїдів у соснових лісах Житомирської області. Науковий вісник НЛТУ України. 2019, т. 29, № 8. С. 31-35.

Citation APA: Andreieva, O. Yu., Vyshnevskyi, A. V., \& Boliujh, S. V. (2019). Population dynamics of bark beetles in the pine forests of Zhytomyr region. Scientific Bulletin of UNFU, 29(8), 31-35. https://doi.org/10.36930/40290803 
користь верхівкового та шестизубчастого короїдів. Ми висловили гіпотезу, що відбувається не один подовжений спалах масового розмноження короїдів, а два спалахи різних угруповань короїдів. Для підтвердження цієї гіпотези важливо було простежити динаміку популяційних показників найпоширеніших видів під час їхнього масового розмноження у лісах Житомирської обл., що й є метою нашого дослідження.

Об'єкт дослідження - популяційні показники короїдів у соснових насадженнях.

Предмет дослідження - дев'ятирічна динаміка поширеності, щільності поселень, продукції потомства та енергії розмноження чотирьох видів короїдів у соснових насадженнях Житомирської області.

Передбачалося виконання таких завдань:

- виявити роки максимального значення площі осередків "короїдного" всихання у лісовому фонді Житомирської області та лісогосподарські підприємства 3 найбільшим розвитком спалахів;

- під час польових досліджень на модельних деревах в осередках "короїдного" всихання визначити видовий склад i популяційні показники короїдів;

- за даними, усередненими для кожного року, побудувати графіки динаміки поширеності, щільності поселень, продукції потомства та енергії розмноження чотирьох видів короїдів за 2011-2019 pp. та порівняти значення популяційних показників кожного року 3 "нормативними" значеннями (Meshkova et al., 2010), характерними для відповідних видів комах.

Матеріал і методи дослідження. В аналізі використали матеріали статистичної звітності Житомирського обласного управління лісового господарства, Державного спеціалізованого лісозахисного підприємства (ДСЛП) "Вінницялісозахист" (Anonimous, 2018) i peзультати власних польових досліджень. Польові дослідження здійснювали у 2013-2019 рр. в осередках всихання соснових насаджень у лісовому фонді державних лісогосподарських підприємств: "Коростишівське ЛГ", "Житомирське ЛГ", "Баранівське ЛГ", "Попільнянське ЛГ", "Білокоровицьке ЛГ", "Малинське ЛГ" та "Ємільчинське ЛГ".

Поширеність поселень тих чи інших видів короїдів визначали як частку дерев 3 ознаками поселення особин певного виду від кількості оглянутих дерев. Зважаючи на те, що малий сосновий лубоїд і верхівковий короїд заселяють переважно ділянки стовбурів із тонкою корою, здійснювали ентомологічний аналіз зрубаних дерев.

Популяційні показники короїдів оцінювали на палетках, які закладали на стовбурах і гілках дерев сосни (Meshkova et al., 2010). За довжини окружності відрізку стовбура понад 25 см розмір облікових палеток становив $25 \times 25$ см, а за меншої довжини окружності відрізку стовбура або відрізку гілки палетки мали довжину не меншу ніж 10 см, а ширина дорівнювала довжині окружності відповідного зразка.

На палетках стосовно кожного виявленого виду визначали щільність поселення та продукцію. Показник щільності поселення охоплював кількість родин (шлюб-

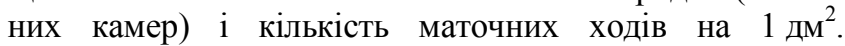
Водночас, під час зіставлення щільності поселення різних видів короїдів брали до уваги лише показники щільності маточних ходів, "нормативні" значення яких наведено для всіх чотирьох видів (Meshkova et al., 2010).

Продукцію визначали як кількість особин молодого покоління короїдів, що вилетіли з поверхні 1 дм². Енер- гію розмноження кожного виду короїдів розраховували діленням показника щільності поселення на продукцію. Усі визначені показники порівнювали з "нормативними" значеннями для кожного виду короїдів (Meshkova et al., 2010). Загалом проаналізовано 550 палеток на 61 модельному дереві.

Результати оцінювання популяційних показників на окремих модельних деревах аналізували методами описової статистики, а окремі вибірки порівнювали з використанням дисперсійного аналізу (Atramentova, Utevskaya, 2008), який здійснювали засобами пакету програм MS Excel.

Результати дослідження. Площа осередків, як одержали назву осередків "короїдного" всихання, наростала до 2017 р., а коли перевищила 40 тис. га, то почала зменшуватися (рис. 1).

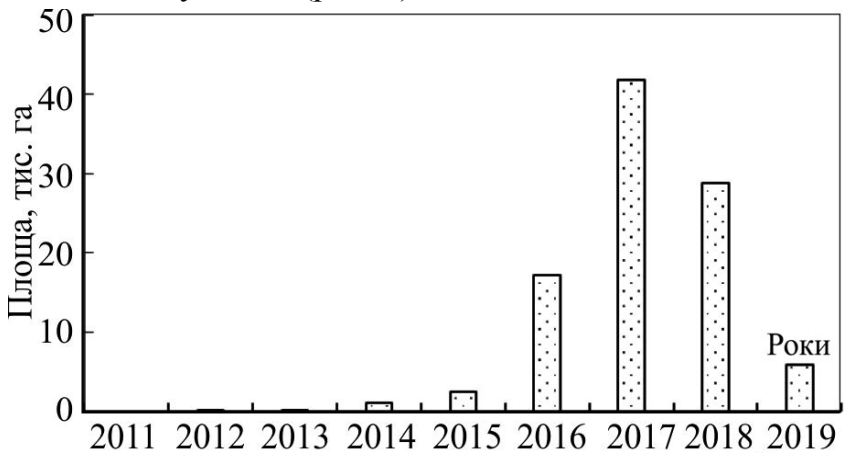

Рис. 1. Площа осередків "короїдного" всихання у лісовому фонді Житомирського ОУЛМГ (за даними ДСЛП "Вінницялісозахист")

Найбільшою мірою площі осередків "короїдного" всихання наростали в лісовому фонді державних лісогосподарських підприємств: "Коростишівське ЛГ", "Житомирське ЛГ", "Баранівське ЛГ", "Попільнянське ЛГ", "Білокоровицьке ЛГ", "Малинське ЛГ" та "Смільчинське ЛГ", що видно за даними про площі вибіркових санітарних рубок (рис. 2).

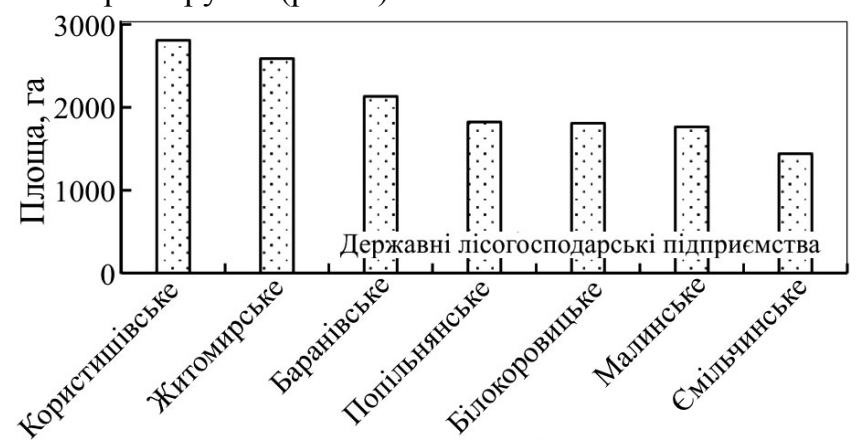

Рис. 2. Площа вибіркових санітарних рубок у соснових насадженнях державних лісогосподарських підприємств Житомирського ОУЛМГ, в яких у 2017 р. виявлено найбільші осередки "короїдного" всихання (за даними ДСЛП "Вінницялісозахист")

Поширеність стовбурових шкідників у межах 2160 \% вважаємо середньою, а перевищення верхньої межі цього діапазону свідчить про наявність спалаху масового розмноження певного виду (Meshkova et al., 2010).

У комплексі стовбурових шкідників, що заселяли дерева сосни в роки досліджень, у 2014 р. переважали соснові лубоїди (рис. 3). Водночас, у 2015 р. поширеність цих видів зменшилася, а поширеність верхівкового та шестизубчастого короїдів почала збільшуватися. У 2016 р. поширеність верхівкового короїда перевищи- 
ла верхню межу "міжспалахової" чисельності, у 2017 р. досягла $85 \%$, у 2018 р. трималася на високому рівні (66 \%), а у 2019 р. знизилася до середнього рівня. Поширеність шестизубчастого короїда змінювалася майже синхронно 3 верхівковим. Обидва ці види замістили в екосистемі звичних соснових лубоїдів, які мають лише одне покоління на рік, і тому не можуть конкурувати 3 мультивольтинними видами (Meshkova et al., 2017). У 2018 р. визначено тенденцію до зменшення поширеності верхівкового та шестизубчастого короїдів і збільшення поширеності соснових лубоїдів, яке розпочалося ще у 2016 р. (див. рис. 3 ).

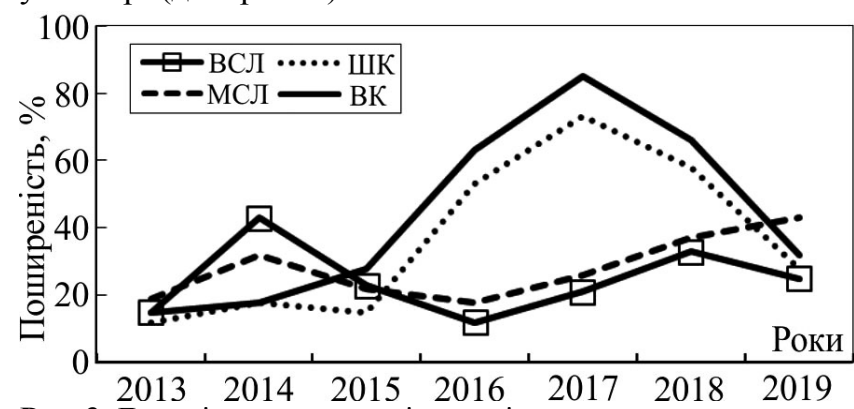

Рис. 3. Динаміка поширеності короїдів в осередках всихання в лісовому фонді Житомирського ОУЛМГ у 2013-2019 рр. (ВСЛ - великий сосновий лубоїд; МСЛ - малий сосновий лубоїд; ШК - шестизубчастий короїд; ВК - верхівковий короїд)

Подібні закономірності динаміки популяцій окремих видів короїдного комплексу виявляються також у значеннях інших популяційних показників (рис. 4-6).

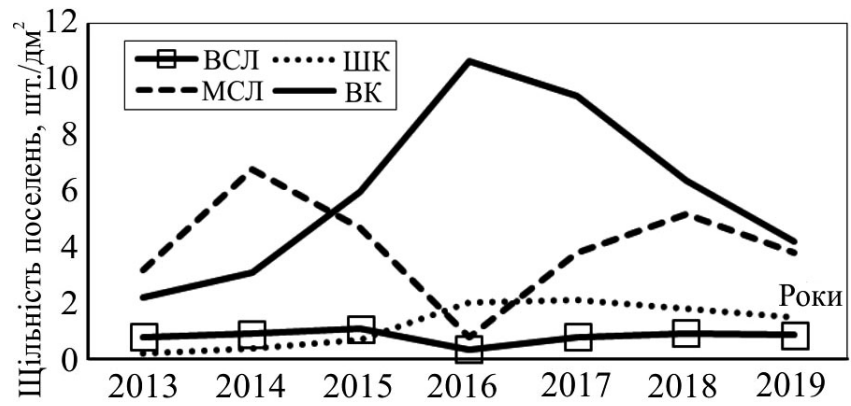

Рис. 4. Динаміка щільності поселень короїдів в осередках всихання в лісовому фонді Житомирського ОУЛМГ у 2013-2019 pp. (ВСЛ - великий сосновий лубоїд; МСЛ - малий сосновий лубоїд; ШК - шестизубчастий короїд; ВК - верхівковий короїд)

За період наших досліджень основні тенденції розвитку комплексу короїдів у соснових насадженнях лісового фонду Житомирського ОУЛМГ визначала динаміка популяцій домінантного виду - верхівкового короїда. Щільність поселень цього виду мала тенденцію до зростання до 2016 р., коли збільшувалася кількість ослаблених дерев, доступних до заселення. Водночас, щільність популяцій цього виду у 2016 р. у середньому в 2,14 раза перевищила "нормативний" показник (фактична - 10,7 шт./дм², "нормативна" - до 5,0 шт./дм²) (Meshkova et al., 2010). Поступово відчувався тиск конкуренції особин одного виду та міжвидової. Так, 3 2016 р. почала зростати щільність заселення дерев малим сосновим лубоїдом, хоча навіть у 2017 р. вона залишалася на середньому рівні (фактична - 3,8 шт./дм², "нормативна" - до 6,5 шт./дм²).

Щільність поселень шестизубчастого короїда досягла максимуму у 2017 р. та дещо перевищила "нормативні" значення (фактична - 2,1 шт./дм², "нормативна" - до 1,2 шт./дм²) (Meshkova et al., 2010). Основним конкурентом цього виду є великий сосновий лубоїд, який та- кож заселяє сосни в нижній частині стовбура, але має лише одну генерацію на рік (Meshkova, 2017). Щільність поселень великого соснового лубоїда була мінімальною у 2016 р. (0,3 шт./дм²), а вже у 2018 р. досягла середнього рівня (фактична - 0,93 шт./дм², "нормативна" для середнього рівня - 0,8-1,5 шт./дм²). Одночасно щільність поселень шестизубчастого короїда повільно зменшувалася і становила станом на 2019 р. 1,5 шт./дм ${ }^{2}$ ("норматив" для середнього рівня - до 0,6-1,2 шт./дм²) (Meshkova et al., 2010). Аналогічно змінювалася продукція аналізованих видів короїдів (див. рис. 5). Максимальне іiї значення визначено у верхівкового короїда у 2017 p. (39,5 шт./дм²), що майже в 4 рази перевищує "норматив" (10 особин/ дм²).

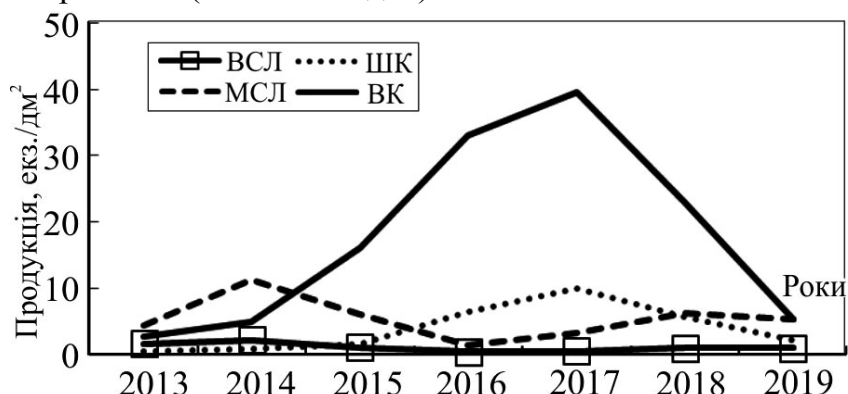

Рис. 5. Динаміка продукції короїдів в осередках всихання в лісовому фонді Житомирського ОУЛМГ у 2013-2019 рр. (ВСЛ великий сосновий лубоїд; МСЛ - малий сосновий лубоїд; ШК шестизубчастий короїд; ВК - верхівковий короїд)

Продукція шестизубчастого короїда досягла у 2017 p. 10,1 шт./дм² ("норма" - 4 шт./дм²) (Meshkova et al., 2010). За такої щільності популяцій верхівкового та шестизубчастого короїдів в осередках їхнього масового розмноження зросла чисельність ентомофагів, які переважно не діють вибірково, а знищують різні види короїдів. Так, під час оглядання окоренкової частини стовбурів сосни на початку квітня 2019 р. було виявлено у значній кількості хижі комахи: чорниші рудий сосновий Corticeus pini (Panzer, 1799) та Uloma rufa (Piller et Mitterpacher, 1783) (Tenebrionidae), мурахожук Thanasimus formicarius (Linnaeus, 1758) (Cleridae), блищанка чотирицяткова Glischrochilus quadripustulatus (Linnaeus, 1758) (Nitidulidae), козявка мавританська Tenebroides mauritanus (Linnaeus, 1758) (Ostomatidae), а також карапузики (Histeridae): Platysoma elongatum (Thunber, 1787), Paromalus parallelipipedus (Herbst, 1792), Gnathoncus buyssonii (Auzat, 1917), Gnathocerus nanus (Scriba, 1790) (Andreieva et al., 2019).

Оскільки найуразливішими є яйця та личинки молодших віків, продукція видів-конкурентів зросла ненабагато - продукція великого соснового лубоїда становила у 2018 і 2019 рр. лише 1 шт./дм² за нижньої "норми" середнього значення 3,1 шт./дм², а малого соснового лубоїда - 6,2 і 5,3 шт./дм² у 2018 і 2019 рр. відповідно за нижньої "норми" середнього значення 6,1 шт./дм² (Meshkova et al., 2010) (див. рис. 5).

Динаміка значень енергії розмноження короїдів підтверджує висновки, що викладені вище під час аналізу інших популяційних показників короїдів (див. рис. 6).

Енергія розмноження верхівкового та шестизубчастого короїдів зростала до максимальних значень у 2017 p. (4,2 і 4,8 раза відповідно), а цей показник великого та малого соснових лубоїдів за роки досліджень не перевищував середніх значень за "нормою" (1,1-3,0 раза) (Meshkova et al., 2010). 


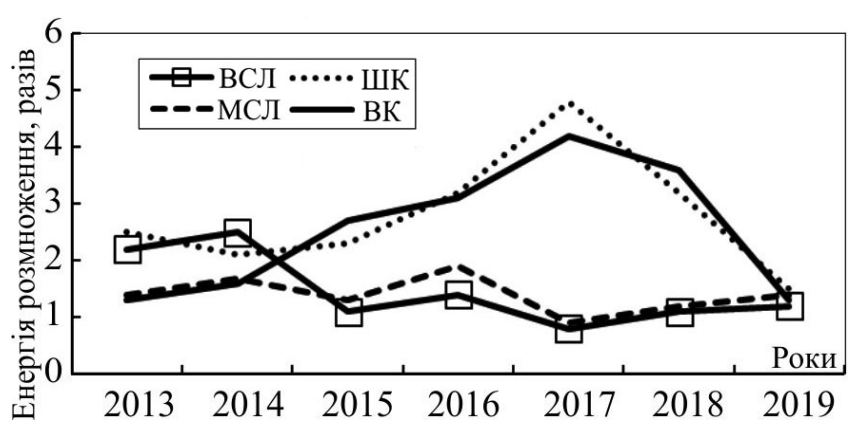

Рис. 6. Динаміка енергії розмноження короїдів в осередках всихання в лісовому фонді Житомирського ОУЛМГ у 2013-2019 pp. (ВСЛ - великий сосновий лубоїд; МСЛ - малий сосновий лубоїд; ШК - шестизубчастий короїд; ВК - верхівковий короїд)

Обговорення результатів дослідження. Багаторічну динаміку популяційних показників короїдів докладно вивчено в ялинових лісах (Grodzki et al., 2014), де абсолютно домінує Ips typographus (Linnaeus 1758). Ми в осередках "короїдного" всихання соснових лісів дослідили динаміку популяційних показників чотирьох видів короїдів. Великий сосновий лубоїд і шестизубчастий короїд заселяють зазвичай нижню частину стовбурів сосни із грубою корою, а малий сосновий лубоїд і верхівковий короїд - частину стовбурів із тонкою корою (Meshkova et al., 2010). Відповідні "пари" є конкурентами за район поселення. Великий сосновий лубоїд має переваги перед шестизубчастим короїдом, тому що починає літ навесні дещо раніше, але поступається йому, оскільки має лише одне покоління на рік в усьому ареалі (Meshkova et al., 2017). Великий сосновий лубоїд заселяє більш життєздатні дерева, ніж шестизубчастий короїд, які спочатку ослаблює під час додаткового живлення лубом пагонів (Öhrn et al., 2018; Özcan et al., 2018). Малий сосновий лубоїд ослаблює дерева під час додаткового живлення лубом пагонів та має одне покоління на рік, тоді як верхівковий короїд, який також ослаблює дерево під час додаткового живлення лубом гілок чи верхньої частини стовбура, але має, як і шестизубчастий короїд, декілька поколінь на рік (Meshkova et al., 2017).

Усі зазначені види короїдів мають близький перелік природних ворогів, переважно хижих комах (Sarikaya \& Ibis, 2016; Orlov et al., 2018; Andreieva, 2019). Тому в роки, сприятливі для зростання чисельності короїдів, переваги мають мультивольтинні види - верхівковий і шестизубчастий короїди (Meshkova et al., 2017), а в роки згасання спалахів цих видів, переважно внаслідок внутрішньовидової конкуренції, види-конкуренти не можуть швидко відновити чисельність, оскільки в осередку накопичується великий запас ентомофагів (Тhomaes et al., 2017; Orlov et al., 2018; Meshkova et al., 2019).

Висновки. За період 2011-2019 рр. площа осередків "короїдного" всихання у соснових лісах Житомирської обл. зростала до 2017 p.

У комплексі короїдів в осередках всихання до 2014 р. переважали соснові лубоїди, а з 2015 р. - верхівковий і шестизубчастий короїди, які мають декілька поколінь на рік.

Основні тенденції розвитку комплексу короїдів у соснових насадженнях у роки досліджень визначала динаміка популяцій домінантного виду - верхівкового короїда.

Значення показників поширеності, щільності поселень, продукції та енергії розмноження окремих видів короїдів свідчать про посилення 32016 р. внутрішньо- видової конкуренції в популяції верхівкового короїда, а у 2018-2019 рр. - також міжвидової конкуренції.

3 огляду на дію конкуренції та накопичення ентомофагів в осередках всихання варто очікувати згасання спалахів масового розмноження короїдів. Наступні дослідження мають бути спрямовані на кількісне оцінювання впливу ентомофагів на динаміку популяцій короїдів у соснових лісах.

\section{Перелік використаних джерел}

Andreieva, O. Y. (2016). Stem pests in the foci of pine stands decline in the State Enterprise "Zhytomyr Forest Economy" of Zhytomyr region. The Bulletin of Kharkiv National Agrarian University. Series: Phytopathology and Entomology, 1-2, 3-9. [In Ukrainian with English summary].

Andreieva, O. Y. (2019). Hibernation of stem pests and their entomophages in the pine stands of Central Polissya. Pine forests: Current status, existing challenges and ways forward: Proceedings of International Scientific and Practical Conference, Kyiv, June 1213, 2019. (pp. 91-93). Kharkiv: Planeta-print. [In Ukrainian].

Andreieva, O. Y., \& Goychuk, A. F. (2018). Spread of Scots pine stands decline in Korostyshiv Forest Enterprise. Forestry and Forest Melioration, 132, 148-154. https://doi.org/10.33220/1026-3365.132.2018.148

Andreieva, O. Y., Guzii, A. I., \& Vyshnevskyi, A. V. (2018 b) Poshyrennya oseredkiv masovoho rozmnozhennya koroyidiv u sosnovykh nasadzhennyakh Rivnens'koho Polissya. [Spread of bark beetlese foci in pine stands of Volodymyretske forest enterprise]. $\begin{array}{llll}\text { Scientific Bulletin of UNFU, 28(3), 14-17. } & \end{array}$ https://doi.org/10.15421/40280302

Andreieva, O., Zhytova, O., \& Martynchuk, I. (2018a). Health condition and colonization of stem insects in Scots pine after ground fire in Central Polissya. Folia Forestalia Polonica, 60(3), 143-153. https://doi.org/10.2478/ffp-2018-0014

Anonimous (2018). Report materials about the spread of diseases and pests in the forest stands of Zhytomyr Regional Forest and Hunting Administration in 2017 and prognosis for 2018. State Specialized Forest Protective Enterprise "Vinnytsyalisozahyst", 70 p. [In Ukrainian].

Atramentova, L. A., \& Utevskaya, O. M. (2008). Statistical methods in biology. Gorlovka, 148 p. [In Russian].

Biedermann, P. H., Müller, J., Grégoire, J. C., Gruppe, A., et al. (2019). Bark Beetle Population Dynamics in the Anthropocene: Challenges and Solutions. Trends in ecology \& evolution. https://doi.org/10.1016/j.tree.2019.06.002

Borodavka, V. O., Getmanchuk, A. I., Kychyljuk, O. V., \& Vojtjuk, V. P. (2016). Pathological processes of declining pine stands in Volyn Polissya. Scientific Bulletin of NULES of Ukraine. Series: Forestry and decorative gardening, 238, 102-118. Retrieved from: http://nbuv.gov.ua/UJRN/nvnau lis 2016238 14. [In Ukrainian].

Davydenko, K., Vasaitis, R., \& Menkis, A. (2017). Fungi associated with Ips acuminatus (Coleoptera: Curculionidae) in Ukraine with a special emphasis on pathogenicity of ophiostomatoid species. European Journal of Entomology, 114, 77-85. https://doi.org/10.14411/eje.2017.011

Getmanchuk, A., Kychylyuk, O., Voytyuk, V., \& Borodavka, V. (2017). Regional climate changes as primary cause of pine stands decline in Volyn Polissya. Scientific Bulletin of UNFU, 27(1), 120124. https://doi.org/10.15421/40270127

Grodzki, W., Starzyk, J. R., \& Kosibowicz, M. (2014). Variability of selected traits of Ips typographus (L.) (Col.: Scolytinae) populations in an area affected by bark beetle outbreak in Beskid Żywiecki (Western Carpathians, Poland). Folia Forestalia Polonica, Series A -Forestry, 56(2), 79-92. https://doi.org/10.2478/ ffp-2014-0008

Jaime, L., Batllori, E., Margalef-Marrase, J., Navarro, M. Á. P., \& Lloret, F. (2019). Scots pine (Pinus sylvestris L.) mortality is explained by the climatic suitability of both host tree and bark beetle populations. Forest Ecology and Management, 448, 119-129. https://doi.org/10.1016/j.foreco.2019.05.070 
Kukhta, V. N., \& Sazonov, A. A. (2019). Features of the pine bark beetle (Ips acuminatus (Gyllenhal, 1827) Coleoptera: Curculionidae, Scolytinae) development in pine forests of Belarus. Pine forests: current status, existing challenges and ways forward: Proceedings of International Scientific and Practical Conference, Kyiv, June 1213, 2019. (pp. 54-61). Kharkiv: Planeta-print. [In Russian].

MacQuarrie, C. J., Lyons, D. B., Seehausen, M. L., \& Smith, S. M. (2016). A history of biological control in Canadian forests, 18822014. The Canadian Entomologist, 148(1), 239-269. https://doi.org/10.4039/tce.2015.66

Meshkova, V. L. (2017). Evaluation of harm (injuriousness) of stem insects in pine forest. Scientific Bulletin of UNFU, 27(8), 101-104. https://doi.org/10.15421/40270816

Meshkova, V. L. (2019). Decline of pine forest in Ukraine with contribution from bark beetles: causes and trends. Izvestia Sankt-Peterburgskoj Lesotehniceskoj Akademii, 228, 312-335. https://doi.org/10.21266/2079-4304.2019.228.312-335

Meshkova, V. L., \& Borysenko, O. I. (2017). Dynamics of pine engraver beetle-caused forest decline in Teterivske Forestry Enterprise. Forestry and Forest Melioration, 131, 171-178.

Meshkova, V. L., \& Borysenko, O. I. (2018). Prediction for bark beetles caused desiccation of pine stands. Forestry and Forest Melioration, 132, 155-161. https://doi.org/10.33220/10263365.132.2018.155

Meshkova, V. L., et al. (2010). Methodical recommendations for the survey in the foci of forest stem pests. Kharkiv: UkrNDILGA, $27 \mathrm{p}$.

Meshkova, V. L., Kochetova, A. I., Zinchenko, O. V., \& Skrylnik Yu. Ye. (2017). Biology of multivoltine bark beetle species (Coleoptera: Scolytinae) in the North-Eastern Steppe of the Ukraine. (Ser. Phytopathology and Entomology). The Bulletin of Kharkiv National Agrarian University, 1-2, 117-124.

Meshkova, V. L., Ridkokasha, A. D., \& Omelich, A. R. (2019). The first results of entomophags use in forest protection from stem pests. Pine forests: current status, existing challenges and ways forward: Proceedings of International Scientific and Practical Conference, Kyiv, June 12-13, 2019. (pp. 141-143). Kharkiv: Planetaprint. [In Ukrainian with English summary].

Neuvonen, S., \& Viiri, H. (2017). Changing climate and outbreaks of forest pest insects in a cold northern country, Finland. In The Interconnected Arctic-UArctic Congress 2016. (pp. 49-59). Springer, Cham. https://doi.org/10.1007/978-3-319-57532-2_5

Öhrn, P., Björklund, N., \& Långström, B. (2018). Occurrence, performance and shoot damage of Tomicus piniperda in pine stands in southern Sweden after storm - felling. Journal of applied entomology, 142(9), 854-862. https://doi.org/10.1111/afe.12331
Økland, B., Flø, D., Schroeder, M., Zach, P., et al. (2019). Range expansion of the small spruce bark beetle Ips amitinus: a newcomer in northern Europe. Agricultural and Forest Entomology, 21, 286298. https://doi.org/10.1111/afe.12331

Orlov, O. O., Zhukovs'kyy, O. V., \& Kushnir, L. S. (2018). Entomophagous insects in the foci of stem pests in the Zhytomyr Polissya. Ekolohichna naukova diyal'nist': v kontseptsiyi staloho rozvytku: Zbirnyk statey naukovo-praktychnoyi konferentsiyi z mizhnarodnoyu uchastyu, Zhytomyr, December 4, 2018. (pp. 222-227). Zhytomyr: Vyd-vo ETS. [In Ukrainian].

Özcan, G. E., Enez, K., \& Arıcak, B. (2018). Effects of forest roads on Ips sexdentatus infestation in black pine forest. Turkish Journal of Agriculture-Food Science and Technology, 6(7), 828-833. https://doi.org/10.1111/jen.12533

Sarikaya, O., \& Ibis, H. M. (2016). Predatory species of bark beetles in the pine forests of Izmir region in Turkey with new records for Turkish fauna. Egyptian Journal of Biological Pest Control, 26(3).

Sazonov, A. A., Kukhta, V. N., \& Tapchevskaya, V. A. (2017). Outbreak of mass reproduction of pine engraver beetle (Ips acuminatus (Gyllenhal, 1827), Scolytinae, Coleoptera) in the forests of the Byelorussian Polesie. Results and prospects of development of entomology in Eastern Europe: a collection of articles of the II International Scientific and Practical conference, Minsk, September 6-8, 2017. (pp. 366-378). Eds: O. I. Borodin, V. A. Tsinkevich, A. N. Varaksin. [In Russian].

Shvidenko, A., Buksha, I., Krakovska, S., \& Lakyda, P. (2017). Vulnerability of Ukrainian forests to climate change. Sustainability, 9(7), 1152. https://doi.org/10.3390/su9071152

Sierota, Z., Grodzki, W., \& Szczepkowski, A. (2019). Abiotic and Biotic Disturbances Affecting Forest Health in Poland over the Past 30 Years: Impacts of Climate and Forest Management. Forests, 10(1), 75. https://doi.org/10.3390/f10010075

Skrzecz, I., \& Perlińska, A. (2018). Current problems and tasks of forest protection in Poland. Folia Forestalia Polonica, 60(3), 161172. https://doi.org/10.2478/ffp-2018-0016

Thomaes, A., Drumont, A., Warzée, N., Grégoire, et al. (2017). Ecology and distribution of Thanasimus formicarius (Linnaeus, 1758) and the newly discovered Thanasimus femoralis (Zetterstedt, 1828) in Belgium (Coleoptera: Cleridae). Bulletin de la Société royale belge d'Entomologie, 153, 206-214.

Tkach, V. P., \& Meshkova, V. L. (2019). Modern problems of formation and reproduction of biologically stable pine forests of Ukraine in conditions of climate change. Pine forests: current status, existing challenges and ways forward: Proceedings of International Scientific and Practical Conference, Kyiv, June 12-13, 2019. (pp. 70-77). Kharkiv: Planeta-print. [In Ukrainian with English summary].

O. Yu. Andreieva', A. V. Vyshnevskyi', S. V. Boliujh ${ }^{2}$

${ }^{I}$ Zhytomyr National Agroecological University, Zhytomyr, Ukraine ${ }^{2}$ State Specialized Forest Protective Enterprise "Vinnytsyalisozahyst", Vinnytsya, Ukraine

\section{POPULATION DYNAMICS OF BARK BEETLES IN THE PINE FORESTS OF ZHYTOMYR REGION}

The health condition of Scots pine (Pinus sylvestris L.) forests in Zhytomyr region has deteriorated sharply since the 2009 drought. This phenomenon was initially explained by the negative impact of climatic factors. However, the important role of bark beetles (Coleoptera: Curculionidae: Scolytinae) has been proved, particularly Tomicus piniperda (Linnaeus, 1758), T. minor (Hartig, 1834), Ips acuminatus (Gyllenhal, 1827) and I. sexdentatus (Boerner, 1767). Bark beetles are recognized to be a direct cause of tree mortality after their weakening by any cause. Therefore, it is hypothesized that after the drought of 2009, two outbreaks of different groups of bark beetles occurred. To confirm this hypothesis, we analyzed the dynamics of population indices of the most common species during their mass propagation in the forests of Zhytomyr region for the period of 2013-2019. The analysis of prevalence, parent and progeny population density, and propagation energy of bark beetles obtained on 550 sample points from 61 model trees was carried out. The prevalence was evaluated as the proportion of trees with the signs of bark beetle colonization. Parent population was evaluated by a number of bark beetles' nuptial champers (families) plus a number of mother galleries per 1 sq. dm. Progeny population was evaluated by exit holes number per $1 \mathrm{sq}$. dm. The energy of propagation was evaluated as the ratio of population density of progeny and parents. It is found out that in the bark beetle complex in the foci of drying out until 2014, T. piniperda and T. minor dominated, and since 2015, I. acuminatus and I. sexdentatus dominated, which have several generations per year. It was shown that the main trends in the development of the bark beetle complex in pine stands of Zhytomyr region during the years of research were determined by the dynamics of the populations of I. acuminatus (the dominant species). The values of all population indices show the increase of intraspecific competition in I. acuminatus population since 2016, and interspecific competition in 2018-2019. Competition and the accumulation of entomophages in the foci of drying out are expected to bring to the collapse of the bark beetles' outbreak.

Keywords: foci area; population indices; prevalence; parent population; progeny population; the energy of propagation. 